\title{
大腸と他臓器の重複癌
}

\begin{tabular}{lrrrrr}
\multicolumn{8}{c}{ 愛知県がんセンター外科第 3 部 } \\
加藤 & 知行 & 山内 & 晶司 & 森本 & 剛史 \\
安江 & 満悟 & 高木 & 弘 & 紀藤 & 毅 \\
加藤 & 王千 & 宮石 & 成一 & 中里 & 博昭 \\
山田 & 栄吉 & & & &
\end{tabular}

\section{MULTIPLE PRIMARY MALIGNANCIES-COMBINATIONS OF LARGE BOWEL AND OTHER ORGANS}

\section{Tomoyuki KATO, Akeshi YAMAUCHI, Takeshi MORIMOTO, Mitsunori YASUE, Hiroshi TAKAGI, Tsuyoshi KITO, Kimiyuki KATO, Hiroaki NAKASATO, Seiichi MIYAISHI and Eikichi YAMADA}

Third Department of Surgery, Aichi Cancer Center Hospital

\begin{abstract}
1965 1978年までの大腸腺董症を除く大腸癌手術例の内, 他葴器癌 との 重複例は34例で切除例の3.9\% にあたり，癌患者が第 2 癌を重複する頻度は健康人が初めて癌に䍜患する頻度と変りなかった。 その内訳 は同時性 11 , 異時性 23 : 男子21, 女子13である. 平均年龄は単発大腸癌と变りはない。重複䒽器は大腸癌 では結腸が多く，他蔵器癌では胃，乳腺，子宮に多い。これは剖検例では胃に次いで肺，甲状腺が多いの と異っていた，同時性癌の診断では術前の充分な診察之検查が，そして術中の腹旺内の検索が重要であ る. 異時性癌の第 2 癌の早期猃断率は低く, 今後の問題点である.
\end{abstract}

索引用語 : 大腸癌, 重複癌, 多発癌

\section{はじめに}

近年わが国の悪性腫場による死亡は死因の大きなるの になってきた. 大腸癌についていえばその発生頻度は增 加してきているが，一方診断技術や治療法の進歩むあっ $\tau$, 治瘾切除例 5 年生存率は結腸癌 $78.8 \%$, 直腸癌 $68.6 \%$ とその治療成績は向上している．そして非癌死例 は全く癌に羅患しなかった一般人とほぼ同し頻度で，同 しような原因で死亡している ${ }^{1)}$ 。この中には大腸癌以外 の他の癌により死亡するものが相当数みられるようにな り, 重複癌の存在が大腸癌患者の治療後の予後を左右す る1つの因子として考光なくてはならない時期になった と思われる. そこで今回，大腸癌と他濸器癌との重複例 について検討した。

$$
\text { 対異 }
$$

1965〜1978月までに 当科で扱った大腸癌の primary case で大腸腺腫症を除いた症例を対象とし，重複癌の 定義は Warren \& Gates ${ }^{2)}$ のもの（1）それぞれの癌が 一定の悪性像を有し, (2) 癌の部位が独立していて, (3) 一方が他方の転移の筑いのないるの)にしたがった が，一部組織像が不明なるのでも病歷から考穴て他臟器 の癌を合併していると思われるるのは対象に入れた．第 1 癌手術時から第 2 癌発見時までの期間が 1 年末満のも のを同時性重複癌, 1 年以上のむのを異時性重複癌 と し，それぞれの症例を衰 1 扰よび表 2 亿示した。

尚, 転帰および異時性重袮癌と判定した時限は1980年 1 月 1 日現在のものである.

\section{成}

1. 一般の統計的事項

大腸重複癌は82例で, らち大腸と他臟器との重複例 （以後これを重複癌とよぶ）は34例，大腸癌同志の多発 
表 1 同時性重複癌 1965 1978年手術例

\begin{tabular}{|c|c|c|c|c|}
\hline 症 例 & $\begin{array}{l}\text { 大腸瘦 } \\
\text { 占居部位 }\end{array}$ & 他䑏器的 & 治 & 枟 \\
\hline 1）69才 男 & $T, S^{*}$ & 胆素癌* & $\begin{array}{l}\text { 横行結渴・S 状結腸切除 } \\
\text { 則除 }\end{array}$ & 3 年生存 \\
\hline 2) 55 才 女 & Rs & 孚病 (右) & 直渴切除，爯房切断 & 12年生存 \\
\hline 3）74才 男 & $\mathbf{R b}$ & 胼脱癌 & $\begin{array}{l}\text { 䁤䬧 }{ }^{60} \mathrm{Co} \text { 照射 } \\
\text { 人䀴阿造設 }\end{array}$ & 3 力月稫死 \\
\hline 4) 79才 男 & $\mathrm{Rb} *$ & 肝癌 & 直腸ポリープ㔠除 & 術 死 \\
\hline 5）52才 男 & $\mathbf{R b}$ & 胃 要* & 直淂切断, 胃切除 & 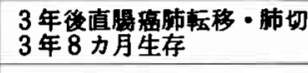 \\
\hline 6）54才 男 & $\mathrm{C}$ & 雸 店* & $\begin{array}{l}\text { 峟半結量切除 } \\
\text { 切除 }\end{array}$ & 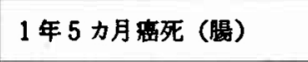 \\
\hline 7) 40 才 女 & D & 冒 癌 & $\begin{array}{l}\text { 右半結渴切除 } \\
\text { 量切除 }\end{array}$ & 11カ月癌死（肝転移） \\
\hline 8）68才 男 & $\mathbf{T}$ & 胃 癌* & $\begin{array}{l}\text { 右半結渴切除 } \\
\text { 骨奶除 }\end{array}$ & 2 年生存 \\
\hline 9）54オ 女 & $\mathrm{S}$ & 胃㾇; & $\begin{array}{l}\mathrm{S} \text { 状結渴切除 } \\
\text { 骨切除 }\end{array}$ & 12年生存 \\
\hline 10）26才 男 & $\mathbf{R b}$ & 胃 瘦 & $\begin{array}{l}\text { 人工肛門造設 } \\
\left(\mathrm{P}_{2} \text { のため) }\right.\end{array}$ & 9 力月看死 \\
\hline 11）69才 男 & $\mathbf{R b}$ & $\begin{array}{l}\text { 畕二廦易カル } \\
\text { チノイド }\end{array}$ & $\begin{array}{l}\text { 人工肛門造設 } \\
\quad\left(\mathrm{H}_{2} \text { のため) }\right.\end{array}$ & 術 死 \\
\hline
\end{tabular}

* : 早期癌 $(m, s m)$ 症例

表 2 異時性重䙉癌 1965 1978年手術例

\begin{tabular}{|c|c|c|c|c|c|c|}
\hline \multirow{2}{*}{ 症 例 } & \multicolumn{2}{|c|}{ 第 1 癌 } & \multirow{2}{*}{$\begin{array}{l}\text { 第 } 1 \text { 盘加ら } \\
\text { 第発戛 } \\
\text { 迄期間 }\end{array}$} & \multicolumn{2}{|c|}{ 第 2 落 } & \multirow{2}{*}{$\begin{array}{l}\text { 第 } 2 \text { 癌治寮後の } \\
\text { 軽㷌 }\end{array}$} \\
\hline & 部 位 & 治 哀 & & 部 位 & 治都 & \\
\hline 1) $69 才$ 男 & $\mathrm{S}, \mathrm{S}$ & S 状結渴切除 & 6 年 & 胃 & 因切除 & 4 力月胃㽽死 \\
\hline 2) 44才 男 & $\mathrm{Rb}$ & 直渴切断 & 5 年 & 胃 & 胃切除 & 1 年 6 力月生存 \\
\hline 3）57才 男 & $\mathrm{Rb}$ & 直膈切断 & 3 年 & 胃 & 胃切除 & 10年生存 \\
\hline 4) 71才 女 & $\mathbf{R a}$ & 直捗切除 & 3 年 & 胃 & 胃切除 & 4 力月周䋹死 \\
\hline 5) 56才 女 & $\mathbf{R b}$ & 直腸切断 & 7 年 & 曹 & 固全㷒 & 1 年 5 力月周瘦死 \\
\hline 6) 39才 女 & $\mathrm{Rb}$ & 直腸切断 & 4 年 & 乳腺 & 釈房切断 & 5 年生存 \\
\hline 7) 52 女 女 & D & 左半結腸切除 & 4 年 & 子 宮 & 他医にて手術 & 5 年生存 \\
\hline 8）55才 女 & $\mathbf{S}$ & S 状結腸切除 & 6 年 & 膵 & 他医にて治痖 & 6 力月拳席死 \\
\hline 9）57才男 & $\mathbf{R a}$ & 直晹切断 & 3 年 9 カ月 & 肺 & 化学家法 & 9 力月肺蕰死 \\
\hline 10）68才 男 & $\mathrm{Rb}$ & 直腸切断 & 5 年 & 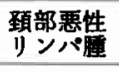 & 放射線治朣 & $\begin{array}{l}\text { 1年 } 2 \text { カ月 } \\
\text { 悪性リンパ㲏死 } \\
\end{array}$ \\
\hline 11）68才 男 & $\mathrm{Rb}$ * & ポリープ剔除 & 4 年 & 肝 & & 肝酒死 \\
\hline 12) 41才 女 & 胃 & 胃切除 & 9 年 & $\mathrm{Ra}$ & $\begin{array}{l}\text { 人工肍門造設 } \\
\left(\mathrm{H}_{3} \text { のため) }\right.\end{array}$ & 5 力月腸茜死 \\
\hline 13）62才 男 & 胃 & 胃切除 & 1 年 & $\mathrm{T}$ & 横行結鹏切除 & 術 死 \\
\hline 14）66才 男 & 胃 & 周切除 & 4 年 & $\mathrm{Ra}, \mathrm{Rb} *$ & 直得切断 & 1 年 6 力月生存 \\
\hline 15）56才 男 & 胃 & 胃切除 & 15年 & $\mathrm{C}$ & 右半結得切除 & 4 年生存 \\
\hline 16）56才 男 & $\begin{array}{l}\text { 胃 } \\
\text { カルチノイド }\end{array}$ & 胃切除 & 9 年 & $\mathrm{S}$ & S 状結搰切除 & 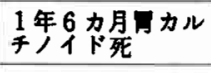 \\
\hline 17）38才 男 & 胃 & 眮切除 & 3 年 & $\mathrm{Rb}^{*}$ & 直回切断 & 1 年霄茈死 \\
\hline
\end{tabular}




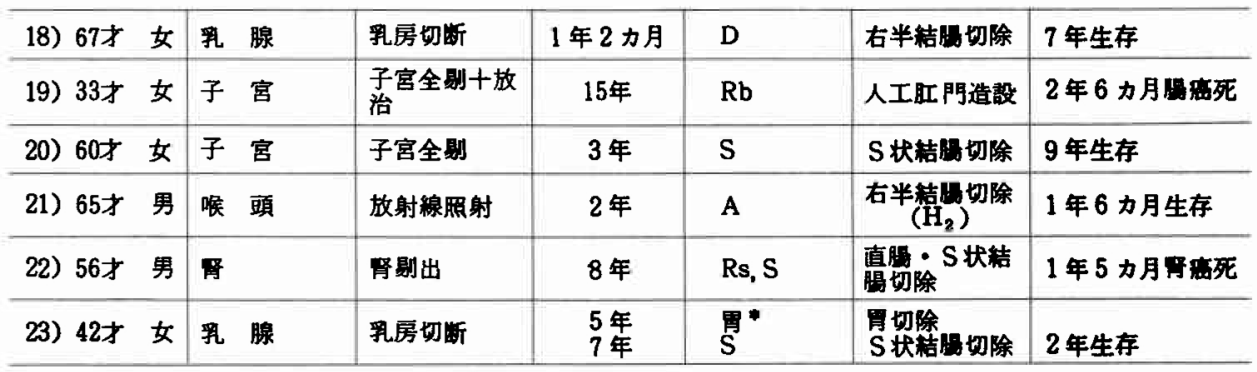

* : 早期癌 $(m, s m)$ 症例，年令は第 1 患発見時

表 3 大腸の重複癌

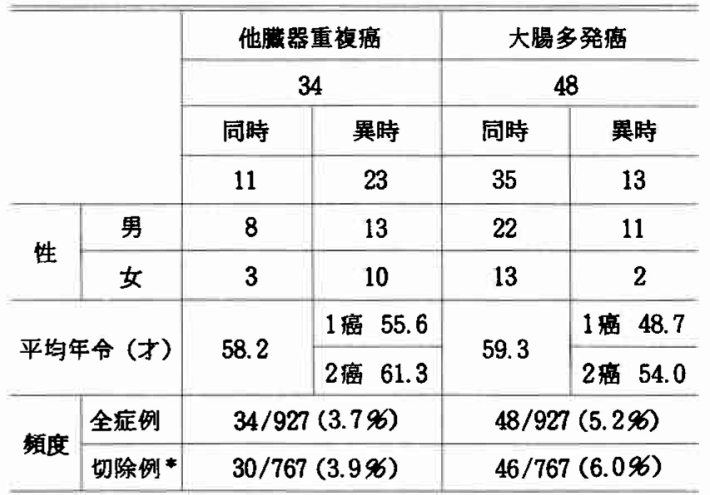

*: 多発癌中の重複㾞 $4 / 46(8.7 \%)$

例 (以後多発癌とよぶ) は48例である（表 3). 重複癌 では同時性11例，異時性23例で異時性癌が多いが，多発 癌では反対に同時性癌が多い. 性比は重複癌, 多発癌共 男子が女子の 2 倍以上を占め, 単発大腸癌では男と女の 比が約 $3: 2$ であるのと比べて 男子に多い. 平均年战 洞時性重複癌は58.2藏, 異時性重複癌の第 1 癌発見時 55.6 歳, 第 2 癌発見時 61.3 歳, 同時性多発癌59.3歳で共 に単発大腸癌の好発年龄にあった．異時性多発癌の第 1 癌発見時年齡は48.7紫と若く, 第 2 癌発見時で54.0歳之 一般の大腸癌と同年㱓層になっている.

重複癌の 発見頻度は大腸癌切除例の $3.9 \%$, 多発癌は $6.0 \%$ であり, 大腸癌切除例のらち約 1 割に 他䑏器重複 癌又は大腸多発癌を合併していることになる.多発癌46

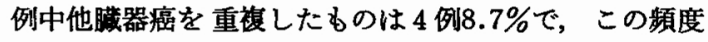
は単発大腸癌が他臟器の癌を重複する頻度の 2 倍以上だ った。

重複癌の組み合わせ内容を表 4 に示した．大晹癌の占 居部位は直腸癌 17 , 結腸癌 13 , 多発癌 4 例であり, 病巣 数にすると直腸 20 病巣, 結腸 18 病巣で, われわれの施設
表 4 重複癌の組合せ

\begin{tabular}{|c|c|c|c|c|}
\hline & & 同時 & 異時 & 計 \\
\hline 直 腸 & 癌 & 6 & 11 & 17 \\
\hline 結 腸 & 湢 & 4 & 9 & 13 \\
\hline 多 発 & 癌 & 1 & 3 & 4 \\
\hline 胃 & 癌 & 7 & 12 & 19 \\
\hline 秏 & 密 & 1 & 3 & 4 \\
\hline 子 宮 & 癌 & & 3 & 3 \\
\hline 盟 のう & 癌 & 1 & & 1 \\
\hline 膀 胜 & 癌 & 1 & & 1 \\
\hline 肝 & 癌 & 1 & 1 & 2 \\
\hline 肺 & 瘦 & & 1 & 1 \\
\hline 荟 & 癌 & & 1 & 1 \\
\hline 㗋 頭 & 瘦 & & 1 & 1 \\
\hline 昌 & 癌 & & 1 & 1 \\
\hline 悪性リンパ & & & 1 & 1 \\
\hline
\end{tabular}

では単発大腸癌の内 $69.6 \%$ が直腸癌であるのと比べると 結腸癌の占める頻度が高い，他䐘器の癌では胃癌が34例 中19例で最す多く，次いで乳癌 4 例，子宮癌 3 例の順た った，女子のみに限っても12例中胃癌が 5 例で最も多 い.すなわち, 重複する他臟器癌は一般の単発癌と同様 に男子では胃癌，女子では胃癌次いで乳癌，子宮癌の頻 度が高い。

\section{2. 同時性重複癌の診断}

同時性重複癌では治療と関連して第 2 癌の診断が重要 となる，自験例についてみると（表1），症例 1 は横行 結腸と S 状結腸の多発癌 として開腹, 術中に䤚のうの 腫瘤を触れて胆のうを剔出したところ $2.3 \times 2.3 \times 2.0 \mathrm{~cm}$ 大の粘膜に限局する癌を合併していたもので，術前には 胆のう癌による症状もなく検索されていない，症例 2 の 
乳癌は術前に医師が 乳房の腫瘤を触れて診断したもの で, 患者は気付いていなかった. 症例 3 は排尿痛により 膀朊癌が発見されて放射線治療を受け，その後に下血が あり直腸癌が発見されている. 症例 4 は直腸癌として入 院し, 肝腫の生検で肝癌が診断された. 下血を control する目的で経肛門的ポリペクトミーを行ったが, 術後 17 日目に肝癌による全身衰弱で死亡した（表には一応術死 として表わしてある). 同時性重複癌で胃癌と合併した むのは症例 5 から 11 までの 7 例であり, 内 4 例か術前に 両方共発見されている. 症例 5 と6はともに胃のもたれ 感といら主訴がありながら，下血又は回盲部腫瘤といら 主訴とは性質の異なる所見があったために胃透視と注腸 撮影が行われて大腸癌と胃癌が発見されたものであり， 症例 7 と 8 は腹部の愁訴に対して胃透視と注腸撮影が行 われている.症例 9 は胃癌として開腹し， $\mathrm{S}$ 状結腸癌を 発見した例である.症例10，11はともにイレウス状態で 直腸癌のみ診断され，それ以上の充分な㭘査は行われて いない, 症例10は術中に, 症例11は剖検で胃癌が発見さ れている. 胃癌との合併例では 7 例中 2 例が多発胃癌だ ったことと, 胃の 9 病変中 4 病变が早期癌だったことが 注目される。

\section{3. 異時性重複癌の診断}

異時性重複癌の 組み合わせをみると（表 2，4）, 胃 癌, 乳癌, 子宮癌は大腸癌の先にす後にも発見されてい る. 大腸癌に先行している癌は喉頭癌之堅癌であり, 大 腸癌の後に発見されたものは膆癌, 肺癌, 肝癌, 悪性リ ンパ腫たった. 大腸癌も含めて比較的予後の良い胃癌, 乳癌, 子宮癌, 喉頭癌は 1 癌にも 2 癌にもなり得るが, 予後の悪い膵, 肺, 肝癌や悪性リンパ腫などは䍜患後に 新らたな癌を発生するだけの生存期間が得られないため に, 第 1 癌にはなりにくいものと思われる.

第 1 癌の術後, 定期的に患者を follow up していれば 第 2 癌は早期に発見されるものと期待されたが, 実際に は第 1 癌が大腸癌だったるので乳癌が 1 例, 第 1 癌が胃 癌または子宮癌だったすので直腸癌がそれぞれ1例ず つ, 結局23例中 3 例が患者の第 2 癌に関する訴兄の前に 医師により発見されたのみで, 残りは全て患者が第 2 癌 または第 3 癌による症状を訴えて来院し，初めて発見さ れたものである. しかも第 2 癌が直腸癌だった先述の 2 例はともに肛門指診で血液付着を認めて発見した例であ り, 発見時には 2 例とむ癌が進行していて人工肛門のみ に終っている.

第 1 癌発見時から第 2 癌発見時までの期間は 1 年から
15 年に拉よび，その分布は 3 年 5 例， 4 年 4 例， 5 年お よび 6 年 2 例ずつで，第 1 癌術後 3 年目から 7 年目まで が第 2 癌がよく発見される時期だつた。平均期間は5.5 年だった。

4. 治療, 予後

同時性重複癌 11 例中両方の癌に対して治瘾手術が行わ れたものは 7 例で，治瘾手術率は63.6\%となり，単発大 腸癌の治瘾切除率の70.5\%と比へてさほど悪くない，治 痊手術が行ない得た症例中 2 例が癌死してお゙り，1例が 再発中であるが， 3 年経過例では 6 例中 4 例，5年経過 例では 4 例中 2 例が生存している.

異時性重複癌の第 1 癌は，喉頭癌に対しては根治的放 射線治療が行われているが，他の症例には全て根治手術 が行われた，症例22の腎癌は腎剔後 6 年目に脳転移, 肺 転移が出現して前後 3 回にわたって転移巣の切除を受 け，その後に直腸の多発癌が発見されて治瘾切除を受け ている.第 1 癌が大腸癌だった11例中, 第 2 癌が膵, 肺, 肝癌および悪性りンパ腫の 4 例は第 2 癌に対して姑 息的治療しか行われていないが，第 2 癌が胃，乳，子宮 癌だったものでは，他医で胃切除を受け詳細が不明な症 例 4,5 を除き, 5 例全例に根治手術が行なわれ，内 1 例が胃癌死しているのみである. 第 $2 ， 3$ 癌が大腸癌だ った12例中大腸癌が進展していて治窑手術のできなかっ たものは 3 例であり, 残りの 9 例には治㾤切除が行われ た（治空切除率 $75.0 \%$ ). 耐術 8 例中癌死例は 2 例で, ともに転移巣の病理組織検查または剖検で第 1 癌である 胃癌の再発と診断され，症例22 腎癌で死亡したが, 経過中に大腸癌の再発は認められなかった。結局, 第 1 癌, 第 2 (3)癌ともに根治的治療が行い得たものは第 1 癌の腎癌の再発中に第 2 癌の大腸癌が発見された症例を 除き 22 例中 13 例 $(59.1 \%$ )で，これは大腸癌と胃癌や乳癌 または子宮癌の組み合わせのものだった。この内，耐術 例12例中 9 例 $(75.0 \%)$ が癌の再発なく生存している.

\section{1. 重複癌の頻度}

他臓器重複癌の頻度を昭和 49 年から昭和53年をでの 5 年間の日本病理剖検輯報》゙によって調べてみると, 全悪 性腫疻の 剖検例 70,804 例中 2,890 例，4.08\%が 重複癌た った。中村) は昭和33〜44年の剖検輯報の集計で重複癌 の頻度を $1.26 \%$, 蓮尾 ${ }^{5)}$ は昭和 44 年〜 48年の集計で 2.46 \%としており，剖検例でみた場合重複癌の頻度は上昇し ている.これは年々悪性腫煌による死亡率が増加してい ることからもうなら゙けることである。 


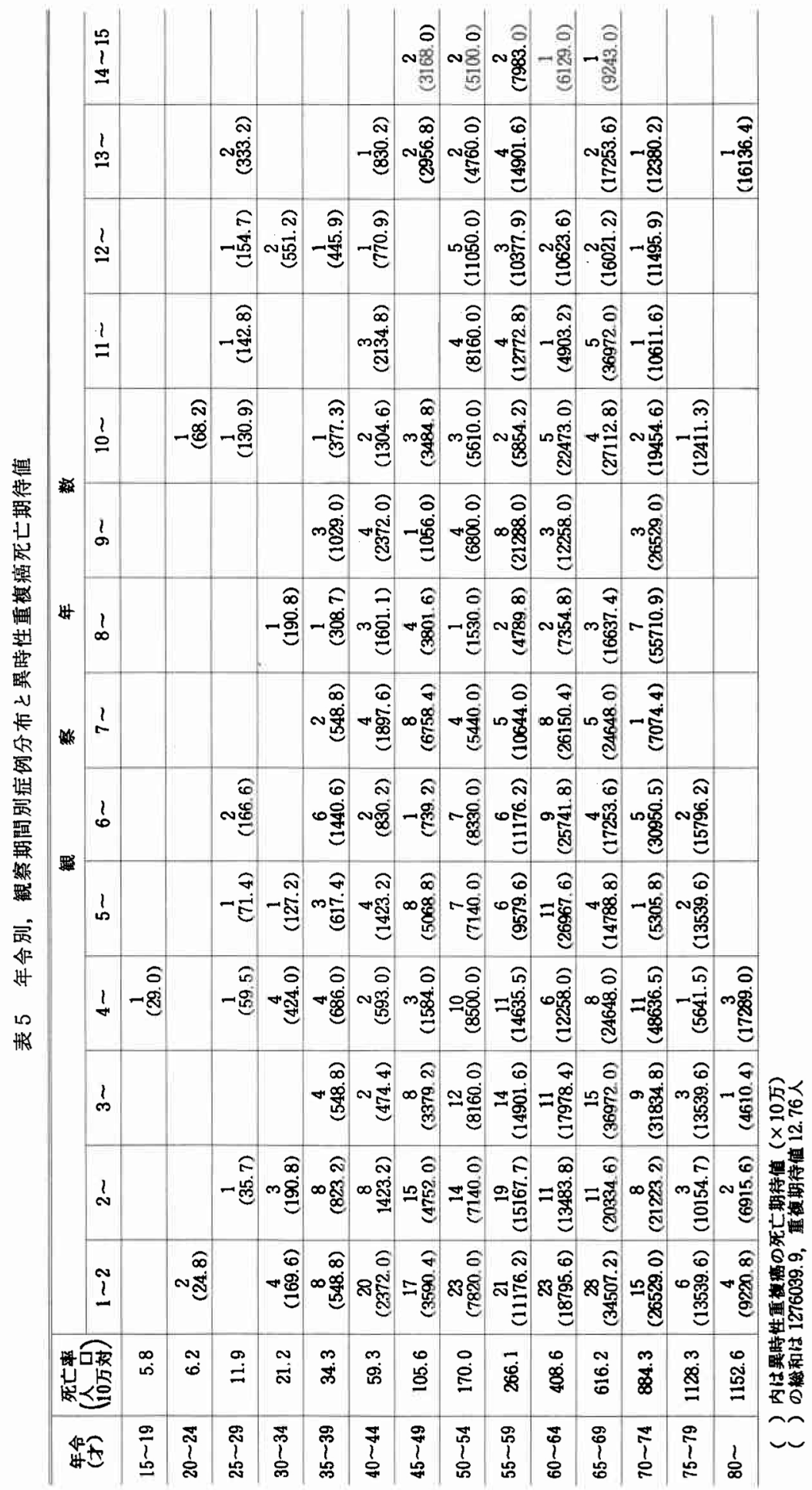


重複癌の頻度については，癌患者または癌の治療を受 けた患者が第 2 癌をるつ確率は, 全く癌のなかった者が 初めて癌になる率よりす高( ${ }^{2(2)}$ とするのが一般的であ った. そこで重複癌がたまたま偶然に発生するもの之仮 定して, 自験大腸癌切除例での重複期待値を異時性癌と 同時性癌とを別々計計算してみた，異時性癌の重複期待 値は，全症例を 5 歳階級に分類し，さらにとれを第 1 回 手術時からの観察期間（生存例は1980月 1 年 1 日まで, 死亡例は生存期間）別に分類し，人口動態統計" 昭和53年度の悪性新生物の年龄別死亡率を使用して, 観 察期間中の第 2 癌による期待死亡数を算出した。すなわ ち, 対象例の異時性重複癌の期待死亡数は（観察期間が 1 年以上経過した患者での年齢別・経過期間別患者数） $\times$ (年龄別癌死亡率) $\times$ (患者別観察期間) の総和で, 12.8 人となった (表 5 ). この 12.8 人の中には第 2 癌が 大腸癌症例となるものも含んでいることになるので，大 腸癌の多発期待数 (人口動態統計") に上ると大腸癌死亡 数 $/$ 全悪性腫場死亡数 $=13,518 / 156,522=8.6 \%=1.1$ 人) を除くと11.7人が 異時性の他葴器重複癌の期待死亡数 となる，藤木ら ${ }^{8)}$ の報告によると，悪性腫瘍の䍜患率は 死亡率の 約1.5倍 であるので11.7人の1.5倍，すなわち 17.6人が異時性重複癌の罹患期待值となる．ところが自 験例の第 1 癌が大腸癌だった症例の異時性重複癌は11例 にすぎなかった。臨床例では現在経過観察中のむのが多 く，実際に癌がありながら発見されていないものもある と考皃なくてはならないが，一旦癌にかかった人がその 後に第 2 癌をむつ頻度は，一般人が初めて癌になる頻度 よりも高いとは決していえないことになる．次に同時性 重複癌の期待値を同様に 5 歳階級に 分類して算出した

(表 6). この易合経過年数は 1 年以内の 発生といらこ とになる。これによって得られた多発大腸癌を含む重複 癌の期待死亡数は 3.45 人であり, 多発大腸癌期待値を除 いた他臓器重複癌の死亡期待値は, $3.45 \times(1-0.086)=$ 3.15 人である. したがって重複癌の罹患期待值は $3.15 \times$ $1.5=5.2$ 人となるが，実際には11人であり約 2 倍だっ た。同時性重複癌の場合，同時性の定義は 2 癌の発見時 期が 1 年以内といらことであって, 実際には 2 つの癌の 発癌時期の隔りは数年はあるであろらから本来ならば重 複期待值は経過年数を考慮して算出されるべきものであ ること（臨床的には経過年数は不明），また臨床上或る 癌が発見されると他の癌む積極的に検索されるので単発 癌ならばもっ之遅れて発見されるような癌が同時に早期 飞発見される（実際化自験例の同時性重複癌の内胃癌を
表 6 年令別，症例分布と同時性重複癌死亡期待値

\begin{tabular}{|c|c|c|c|}
\hline 年令 & (人口10死亡率 & 症例数 & $\begin{array}{c}\text { 発生期待値 } \\
(\times 10 \text { 万 })\end{array}$ \\
\hline 15 19才 & 5.8 & 2 & 11.6 \\
\hline $20 \sim 24$ & 6.2 & 7 & 43.4 \\
\hline $25 \sim 29$ & 11.9 & 18 & 214.2 \\
\hline $30 \sim 34$ & 21.2 & 22 & 466.4 \\
\hline $35 \sim 39$ & 34.3 & 55 & 1886.5 \\
\hline $40 \sim 44$ & 59.3 & 76 & 4506.8 \\
\hline $45 \sim 49$ & 105.6 & 90 & 9504.0 \\
\hline $50 \sim 54$ & 170.0 & 124 & 21080.0 \\
\hline $55 \sim 59$ & 266.1 & 136 & 36189.6 \\
\hline $60 \sim 64$ & 408.6 & 125 & 51075.0 \\
\hline $65 \sim 69$ & 616.2 & 131 & 80722.2 \\
\hline $70 \sim 74$ & 884.3 & 96 & 84892.8 \\
\hline $75 \sim 79$ & 1128.3 & 31 & 34977.3 \\
\hline $80 \sim$ & 1152.6 & 17 & 19594.2 \\
\hline 計 & & & 345164 \\
\hline
\end{tabular}

重複期待値 3.45 人

合併した 7 例中 4 例が早期胃癌だった）ので，同時性重 複癌が 期待值よりも增加するであるらことを考慮する と, 得られた同時性重複癌の期待值が実数の 2 倍とい5 差はもっと小さくなるものであり，同時性重複癌も一般 の人と同様に偶然に起こったものと考えてよい頻度であ る.すなわち, 癌患者が他臓器癌を重複する頻度は同時 性癌も異時性癌も今までいわれてきたように一般健康人 が初めてある癌罣患する頻度よりも5 倍も10倍す高い るのではなく，同程度のものと考えたい。

一方, 他臟器重複癌が 34 例しかないのに, 大腸多発癌 は48例むあることからもわかるように，一度大腸癌に罹 患した者は異時性に大腸癌を多発し易い。

註：本来，期待值は男女别々に算出すべきすのであ

るが, 結果に大きな差がなかったので本論文で は男女を一緒にした表を载せた。

\section{2. 重複臟器}

同年度の日本病理剖検輯報（ただし重袮葴器について は, 昭和51年度のものは記載に誴りがあるので除外し

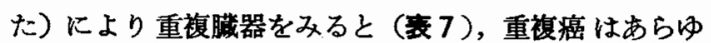
る臓器にみられるが胃癌が $31.4 \% て ゙$ 最も多く，次いで 肺, 甲状腺, 結腸の順である. 直腸と結腸を合わせて大 腸癌としてみると436例，15.1\%を占め，肺に 次いで第 
表 7 全重複癌の塔器別頻度 日本病理剖検輯報 昭和 $49,50,52,53$ 年度，総症例 2890 例，（）\%

\begin{tabular}{|c|c|c|c|}
\hline 1. 胃 & $908(31.4)$ & 10. 前立腺 & $174(6.0)$ \\
\hline 2. 肺 & $566(19.6)$ & 12. 䏾 & $167(5.8)$ \\
\hline 3. 甲状腺 & $425(14.7)$ & 13. 膀 胱 & $127(4.4)$ \\
\hline 4. 結 渴 & $325(11.2)$ & 14. 孚 腺 & $118(4.1)$ \\
\hline 肝 & $325(11.2)$ & 15. 直腸, 肛門 & $111(3.8)$ \\
\hline 6. リンパ造血 & $221(7.6)$ & 16. 卵 果 & $64(2.2)$ \\
\hline 7. 食 道 & $192(6.6)$ & 17. 喉頭 & $59(2.0)$ \\
\hline 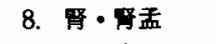 & $186(6.4)$ & 18. 小腸，十二指腸 & $47(1.6)$ \\
\hline 9. 子 宮 & $185(6.4)$ & 19. 咽 頭 & $43(1.5)$ \\
\hline 10. 胆のう, 胆管 & $174(6.0)$ & $\begin{array}{l}20 . \text { 皮 庙 } \\
\text { 他の泌尿器 }\end{array}$ & $\begin{array}{l}37(1.3) \\
37(1.3)\end{array}$ \\
\hline
\end{tabular}

表 8 大腸との重複癌の臟器別頻度，（）\%

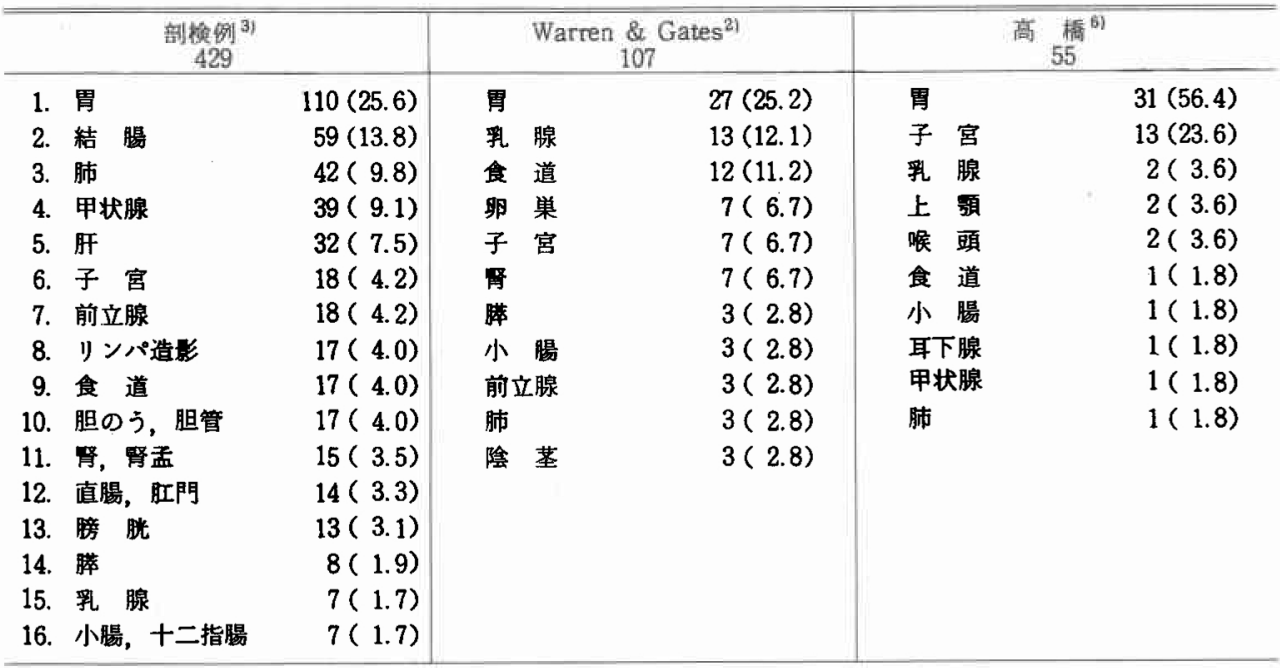

3 番目に重複癌の多い臓器となる．外国では大腸癌は最 も重複癌の多い臟器とされている22。

大晹癌を重複した症例をみると，大腸の単発癌では直 腸癌が多いのであるが多発癌, 重複癌ではとるに結腸 癌の方が多かった．多発癌では単純に発癌の母地の大き さといら点から考えて結腸癌が直腸癌より多いとしても よいが，重複癌については今回集計した剖検輯報で 2 重 癌のみについても，大腸の病巣は結腸303例飞対し直腸 88例と压倒的に結腸に多く, 多発癌や重複癌では大腸の 病巣が結腸に多いことは単発大腸癌と比べて 1 つの特徵 である。

大腸癌と重複する他臟器癌の分布（表 8 ）は，剖検例 では胃癌が最む多く, ついで肺, 甲状腺, 肝の順であ り，表 7 に示した全重複癌の頻度と同様の傾向にあり， とくに大腸癌と重複しやすい傾向の臟器はみられない。
臨床例での大腸癌との重複臓器は自験例では胃癌が最も 多く,ついで乳癌, 子宮癌だった. Warren \& Gates ${ }^{2}$ に よれば（衰 8), やはり大腸癌に重複する癌は胃, 乳腺, 食道の順に多く，高橋"9 和り, 剖検例では肺癌や甲状腺癌が 2,3 位を占めて いるのと異なる. 本邦では大腸癌に関する臨床例の大き な集計がないので胃癌研究会の全国登録10)で臨床例での 胃癌との重複荿器をみると(表9), 直腸, 結腸が最も 多い. 剖検例之比ぺて乳腺, 食道, 喉頭・上頻癌の重複 が多く, 肺, 甲状腺, 白血病, 前立腺癌などが䐓位的に 減少している。これは大腸癌でも胃癌の場合でも臨床例 では症状を有する癌が主として発見，集計されるのに対 して剖検例では根治性が高くすでに治瘦してしまった癌 は往々にして集計からはずれたり，また死因に直接結び つく癌の他に甲状腺癌の样に無症状のまま潜在していた 
表 9 胃癌との重複癌の荿器別頻度（）\%

\begin{tabular}{|c|c|c|c|c|c|}
\hline \multicolumn{2}{|c|}{ 同 $419^{\text {時 }}$} & \multicolumn{2}{|c|}{$346^{\text {時 }}$} & \multicolumn{2}{|c|}{$\begin{array}{l}\text { 棓 } \\
797\end{array}$} \\
\hline 1. 食 道 & $62(14.8)$ & 乳 腺 & $57(16.5)$ & 直 腸 & $108(13.6)$ \\
\hline 2. 直 腸 & $56(14.6)$ & 直 腸 & $50(14.5)$ & 結 腸 & $79(9.9)$ \\
\hline 3. 肝 & $46(11.0)$ & 子 宮 & $49(11.7)$ & 乳 腺 & $72(9.0)$ \\
\hline 4. 膵 & $44(10.5)$ & 結＼cjkstart腸 & $36(10.4)$ & 食 道 & $71(8.9)$ \\
\hline 5. 結 腸 & $41(9.8)$ & 喉頭, 上䫑 & $28(8.1)$ & 肝 & $58(7.3)$ \\
\hline 6. 胆のう & $25(6.0)$ & 肺 & $16(4.6)$ & 子 宮 & $58(7.3)$ \\
\hline 7. 肺 & $19(4.5)$ & 甲状腺 & $15(4.3)$ & 勝 & $54(6.8)$ \\
\hline 8. 乳 腺 & $14(3.3)$ & 膀 胱 & $8(2.3)$ & 肺 & $36(4.5)$ \\
\hline 9. 卵 巣 & $13(3.1)$ & 肝 & $8(2.3)$ & 盟のう & $34(4.3)$ \\
\hline 10. 甲状腺 & $11(2.6)$ & 卵 巣 & $8(2.3)$ & 喉頭，上額 & $33(4.1)$ \\
\hline 11. 膀 睄 & $10(2.4)$ & 勝 & $7(2.0)$ & 甲状腺 & $27(3.4)$ \\
\hline 12. 前立腺 & $9(2.1)$ & 食 道 & $6(1.7)$ & 卵 巣 & $24(3.0)$ \\
\hline 13. 白血病 & $9(2.1)$ & 胆のう & $6(1.7)$ & 膀 胱 & $23(2.9)$ \\
\hline 14. 子 宮 & $7(1.7)$ & 前立腺 & $6(1.7)$ & 白血病 & $17(2.1)$ \\
\hline 15. 胃 & $7(1.7)$ & 舌 & $6(1.7)$ & 前立腺 & $16(2.0)$ \\
\hline 16. 小 腸 & $7(1.7)$ & 白血病 & $6(1.7)$ & 胃 & $12(1.5)$ \\
\hline 17. 喉頭, 上影 & $5(1.2)$ & 皮痛 & $4(1.2)$ & 小 腸 & $10(1.3)$ \\
\hline 18. 皮 间 & $4(1.0)$ & リンバ細網肉䭪 & $4(1.2)$ & 舌 & $9(1.2)$ \\
\hline 19. 腹 膜 & $4(1.0)$ & 胃 & $3(0.9)$ & 皮 膚 & $8(1.0)$ \\
\hline 20．副制腔 & $3(0.7)$ & 他 & $3(0.9)$ & 副買腔 & $6(0.8)$ \\
\hline 舌 & $3(0.7)$ & & & 腹 膜 & $6(0.8)$ \\
\hline 内分泌 & $3(0.7)$ & & & & \\
\hline
\end{tabular}

計には同，異時不明例を含む.

ものも多く集計されるためと思われる．臨床例の自験例 ては, 同時性癌は予後の良いものも悪いものも発見され るが，異時性癌では予後の良い癌は第 1 癌にも第 2 癌に もなり得るのに対し，予後不良な癌は第 2 癌になる事が 多いと思われた。これも同様に胃癌の全国集計（表9） でみると，同時性癌では食道，肝，膡，胆，肺なぞの根 治的治療がむずかしく予後不良の癌が上位を占めている のに対し，異時性癌では乳腺，子宮，喉頭，甲状腺など の予後の良い癌の 合併率が 上昇し，一方，肝，畉巣， 膵, 食道, 胆のらなど予後不良な痹の重複率は減少して いる. 大腸癌の全国集計はまだ始はったばかりでその結 果が出て扣らず明らかではないが, 自験例から推察して も一般に異時性癌では第 1 癌は予後の良い癌が多いるの と考光られる。

\section{3. 重複癌の診断}

重複癌の予後は一般に不良であるが，大腸癌との重複 癌の場合では, 同時性, 異時性を問わず根治的治療がで きた例ではその予後は比較的良い様に思われる，したが って重複癌の早期診断が重要となる。

同時性重複癌の診断については, 術前の詳細な physical examination と充分な検查, 術中の腹腔内蔵器の精
査が第 2 癌を発見するのに肝要である，とくに胃癌との 合併例では自験例でるそうである様に，胃の多発癌と早 期癌の多い(11) 13) ことが特徵であり，これらはともに術 中の視診や触診では発見することが困難な病変であるの で術前に診断して㧍くことが重要である．術中の腹染内 臟器の精査の目的の第 1 は大腸の多発癌の有無を確認す ることだが，同時に術前検查では早期に発見しにくい胆 のう癌や膵臓癌などが術中の触診で発見できる可能性が ある. 異時性癌の猃断については，われわれは第 1 癌の 術後，定期的に患者を follow up していれば異時性第 2 癌も早期に発見できるものと期待していたが，今回の 検討の結果は期待に反するものであり，今後異時性癌の 早期発見にも留意する必要性を痛感した．癌患者が健 康人と比べてとくに第 2 癌を発生しやすいことはないと 既に述べたが，重複癌の 発生しやすい high risk group としては，今回の検討から大腸多発癌症例があげられ，

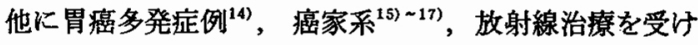
た症例などが考えられている。

\section{おわりに}

大腸と他臟器癌との 重複癌の頻度は大腸癌切除例の $3.8 \%$ であり, 大腸多発癌む含めた広義の重複癌はほほ 
1割を占めていた。これはわれわれが日常診療していて 感じるよりむはるか沉高い率の様に思われる. 大腸癌の 治療成績は消化器癌の内では良好であり，乙たがって重 複癌でもそれぞれの癌が早期に発見されればそれなりの 予後が期待できるものである.同時性癌の診断について は今迄も重複癌の存在を念頭において患者が診察され， 今回の結果でも納得のいく成績だったと思われるが，異 時性重複癌での第 2 癌の早期発見といら点については期 待外えの結果だった。癌患者の術後の follow up 飞際 L, 重複癌をも考虑して行ならといら事の他に, 第 2 癌 が進行して発見された患者の中には定期的に通院してい なかった者が数例あり，術後の定期的な受診を更に徹底 させることの重要性を感じる. 大腸癌患者では術後再び 大腸癌を多発しやすいが，他蔵器癌はとくに発生しやす いわけではない。しかし，多発癌を含む重複癌の有無の check はただ症状の出現するのを観察するのではなく， これからは重複癌を発生しやすい high risk group の患 者を抽出し, 第 2 癌の好発臟器について積極的に第 2 癌 の検索を行う様になると思われる，たた，現在ではまだ high risk group む明らかではなく, 好発臓器も剖検例 と臨床例とでは異なるので, 今後重複癌の臨床について は各臟器毎にこの様な点の検討が必要であろう。

稿を終るに当り発生頻度についてご教示いただいた愛 す知県がんセンター研究所, 疫学部富永祐民部長に深 謝る。

\section{文 献}

1）加藤王千：結腸癌の手術とその成績。癌と化学 療法, 4： 947一953, 1977.

2) Warren, S., Gates, O.: Multiple primary mal- ignant tumors. Am. J. Cancer $16: 1358-1414$, 1932 .

3) 日本病理学会編：日本病理剖検輯報。第18-21 輯, 日本病理剖検輯報刊行会, 1974-1978.

4) 中村恭二, 相沢 幹：組み合せ上りみた重複癌 の検討。癌臨, 18：662一666, 1972.

5) 蓮尾金博活か：セミノーマに合併した大腸早期 癌の一例，癌臨, 22： 879-884, 1976.

6）赤崎兼義注か：原発性重複癌について。日臨， 19:1543-1551, 1961.

7）厚生省大臣官房統計情報部編：昭和53年度人口 動態統計。下巻: 74-75, 厚生統計協会, 1978.

8）藤本伊三郎：厚生省かん研究助成金, 地域がん 登録に上る予防，医療活動の評価に関する研 究。昭和 54 年度報告書, $10-13,1980$.

9）高橋 孝注か：子宮癌・大晹癌重複例。癌臨, $21: 1209-1216,1975$.

10）胃癌研究会編：全国胃が登録調查報告。第 1 ～第12巻, 1963-1973.

11) 三浦敏夫ほか：胃癌之他臓器重複癌。外科, 42: $619-624,1980$

12)阿南敏郎㴗か：当科拈ける重複癌31例の検 討. 外診, 22：697-701, 1980 .

13) 大塚貞光 ほか：重複癌の問題点。外科, 39 : 779-786, 1977.

14）西満正注か：胃の重複癌について。外科, 30: 1115-1125, 1968.

15) Lynch, H.T., et al.: Familial cancer. Surgery $83: 104-113,1978$.

16) Lynch, H.T., et al.: Familial cancer syndromes. Cancer $39:$ 1867-1881, 1977.

17) Low, I.P., et al.: Familial occurence of colon and uterine carcinoma and of lymphoproliferative malignancies. Cancer $39: 1224-1228$, 1977. 